\title{
Vitamin E levels in buccal cells of arsenicosis patients following vitamin E supplementation
}

\author{
Mir Misbahuddin and Nadia Farha
}

Division of Arsenic Research, Department of Pharmacology, Faculty of Basic Medical Sciences and Paraclinical Sciences, Bangabandhu Sheikh Mujib Medical University, Shahbag, Dhaka, Bangladesh.

\begin{tabular}{|lr|}
\hline \multicolumn{2}{|l|}{ Article Info } \\
\hline Received: & 2 May 2013 \\
Accepted: & 13 May 2013 \\
Available Online: & 15 May 2013 \\
DOI: 10.3329/bjp.v8i3.14954 \\
\\
\\
\\
Cite this article: \\
Misbahuddin M, Farha N. Vitamin E \\
levels in buccal cells of arsenicosis \\
patients following vitamin E supple- \\
mentation. Bangladesh J Pharmacol. \\
2013; 8: 236-41.
\end{tabular}

2013; 8: 236-41.

\begin{abstract}
To understand the role of vitamin $\mathrm{E}$ in the treatment of arsenical melanosis and keratosis, the buccal cells of 19 patients, 14 arsenic exposed controls and 13 healthy volunteers were collected for the estimation of vitamin $\mathrm{E}$ both before and after supplementation with vitamin E (200 IU, caplet) daily orally for 20 weeks. The vitamin E levels in the buccal cells of patients were significantly low in comparison to healthy volunteers (healthy vs patients: $17.2 \pm 4.4$ vs $12.3 \pm 6.1 \mu \mathrm{g} / \mathrm{mg}$ of protein; $\mathrm{p}=0.012$ ). These low level of vitamin $\mathrm{E}$ in patients returned toward normal levels following supplementation with vitamin $E$ for 20 weeks $(p=0.044)$. The vitamin $E$ levels in serum of patients were also low (healthy vs patients: $18.9 \pm 4.4$ vs $10.2 \pm 2.6$ $\mu \mathrm{g} / \mathrm{mL} ; \mathrm{p}=0.000)$. Supplementation with vitamin $\mathrm{E}$ overcomed the low levels of vitamin $\mathrm{E}$ in serum. The cholesterol levels in buccal cells and serum of patients were significantly low in comparison to healthy volunteers (buccal levels in both buccal cells and serum of patients.
\end{abstract}

\section{Introduction}

Arsenicosis is primarily presented by melanosis and keratosis (Caussy, 2005; Misbahuddin et al., 2011). Melanosis is usually seen in unexposed parts of the skin whereas keratosis at the palms and soles. These symptoms disappear by stoppage of arsenic consumption. But it is difficult to provide regular intake of arsenic free/safe drinking water by our poor patients. In addition, our foodstuffs are already contaminated with arsenic (Khan et al., 2007). Our foodstuffs contain some unidentified compounds that also help our body to remove arsenic. Foodstuffs are garlic (Misbahuddin et al., 2013), corn (Chowdhury et al., 2009), amaranth leaves, spinach (Umar, 2007), etc. Moreover, supplementation with beta-carotene, vitamin A (Hall, 1946; Ahmad et al., 1998), vitamin C (Ahmad et al., 1998; Saha, 2006), vitamin E (Ahmad et al., 1998), folic acid (Rahman and Misbahuddin, 2010), a-lipoic acid (Tabassum, 2006), zinc (Kamaluddin and Misbahuddin,
2006), selenium (Nasir et al., 2002), spirulina (Fariduddin et al., 2001; Misbahuddin et al., 2006) have the ability to reduce body arsenic load both in animal and human study and may reduce symptoms of melanosis and keratosis. The main problems of supplementation are a) long duration of treatment (3-14 months), b) recur of symptoms after stoppage of supplementation. Coadministration of arsenic with zinc or selenium may enhance the accumulation of arsenic in tissue (Nasir et al., 2002; Misbahuddin and Kamaluddin, 2002). Long duration of supplementation affects the treatment cost of the patient and well as adherence. Most of the arsenicosis patients in Bangladesh are poor.

Therefore, to make the treatment of arsenicosis scientifically sound, we need to know the pathogenesis of this disease. All the above mentioned supplementations are anti-oxidants (Bouayed and Bohn, 2010). The dose of anti-oxidants is critical. High intake of anti-oxidant may act as pro-oxidant (Bouayed and Bohn, 2010). In addi- 
tion, our staple food rice contains hundreds of antioxidants (Yafang et al., 2011). So, why do we need antioxidant supplement? One hypothesis is that the absorption of anti-oxidant as supplement may be better than from anti-oxidant rich diet. Gut bacteria may play a role in the absorption of arsenic (de Wiele et al., 2010; Choudhry et al., 2009).

In the present study, we took vitamin E (mainly prescribed by the physician) as a symbol of a supplement, buccal cells (easily collected from the patient) as a symbol of cell to understand the intracellular environment and a parameter such as intracellular cholesterol level to see whether it is influenced by vitamin E or not.

\section{Materials and Methods}

\section{Study area}

This study was conducted at an arsenic affected area (Village: Eruani; Upazilla: Laksham; District; about 110 km from Dhaka) from October 2010 to June 2011. According to BAMWSP (2004) report, Laksham is an arsenic affected Upazilla where a large number of people have been consuming toxic concentration of arsenic through drinking water. The total area of Laksham Upazilla is $429 \mathrm{~km}^{2}$ with total population of $6,61,866$. There are 1,791 reported cases of arsenicosis and 40,170 tube wells, of which $79.4 \%$ tube wells are contaminated with arsenic $(>50 \mu \mathrm{g} / \mathrm{L})$. The total area of Eruani village is $2.2 \mathrm{~km}^{2}$, with a population of 6,690 and there were 193 tube wells in total. Only five tube wells were safe to drink.

\section{Selection of participants}

Last 100 patients registered in the record book of arsenicosis patients were collected and were contacted them to come to a temporary arsenic clinic (one of the patient's house). All the participants came to the clinic on a selected date. After initial screening of inclusion and exclusion criteria, 47 patients were found to be eligible for the study (Figure 1). Considering the cost of the study, we randomly selected 20 patients who agreed to participate into this study. The diagnosis of patients was confirmed by a dermatologist, presence of high concentration of arsenic in drinking water and nail. Twenty family members exposed to arsenic and 20 non-exposed healthy volunteers were included as control. The number of dropout cases was 1 from patients, 6 from arsenic exposed controls and 7 from healthy volunteers.

Both male and female participants with age range of 18 to 70 years were included in this study. Inclusion criteria for arsenicosis were a) who drank arsenic contaminated water $(>50 \mu \mathrm{g} / \mathrm{L})$ for more than 6 months and b) having physical signs of moderate degree of melanosis and palmar keratosis. The subjects who fulfilled the criteria as arsenic exposed controls were: a) relative or family member of the patient, b) showing no physical signs of melanosis and palmar keratosis, c) shared same tube well water for drinking and cooking purpose with the patient for more than 6 months. The subjects who fulfilled the following criteria were recruited as healthy volunteers: a) drank arsenic safe water $(<50 \mu \mathrm{g} / \mathrm{L}), \mathrm{b})$ lived in the same Upazilla, c) had no cutaneous manifestation and d) subjects who voluntarily agreed to participate

Exclusion criteria includes a) patients having age $<18$ and $>70$ years, b) patients getting treatment of arsenicsis, c) patients of eczema psoriasis, contact dermatitis, and d) subjects who voluntarily did not agree to participate.

\section{Ethical consideration}

The ethical issue of this study was reviewed and approved by the Ethical Committee of Bangabandhu

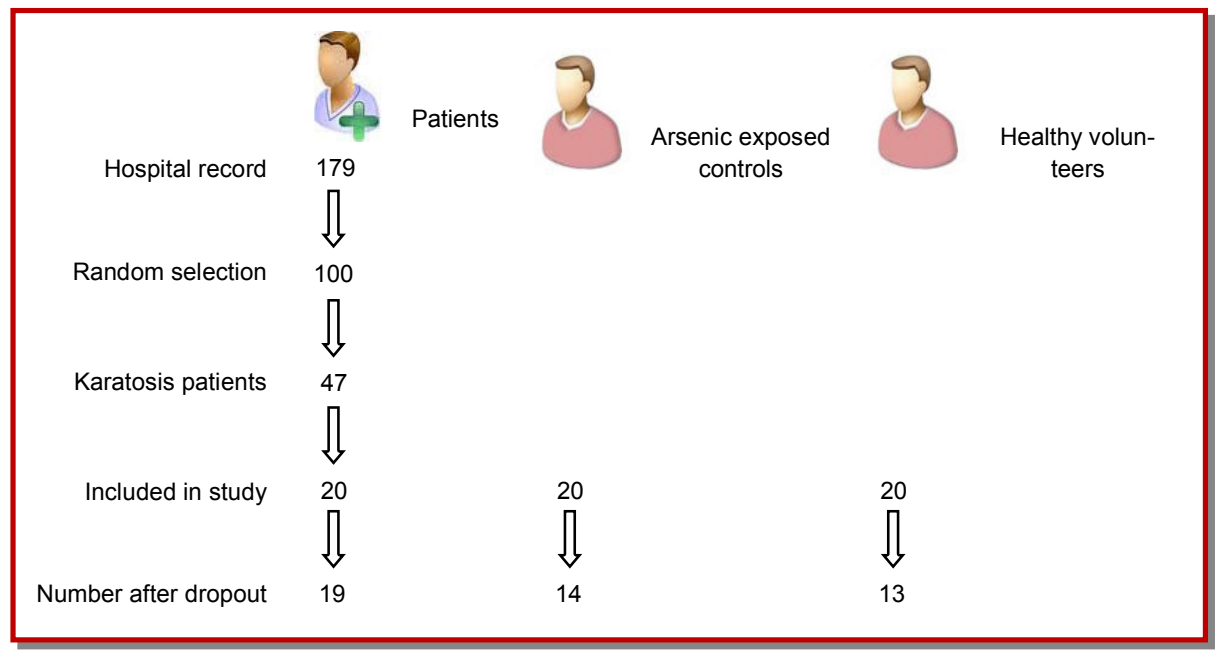

Figure 1: Flow-chart of subject selection 


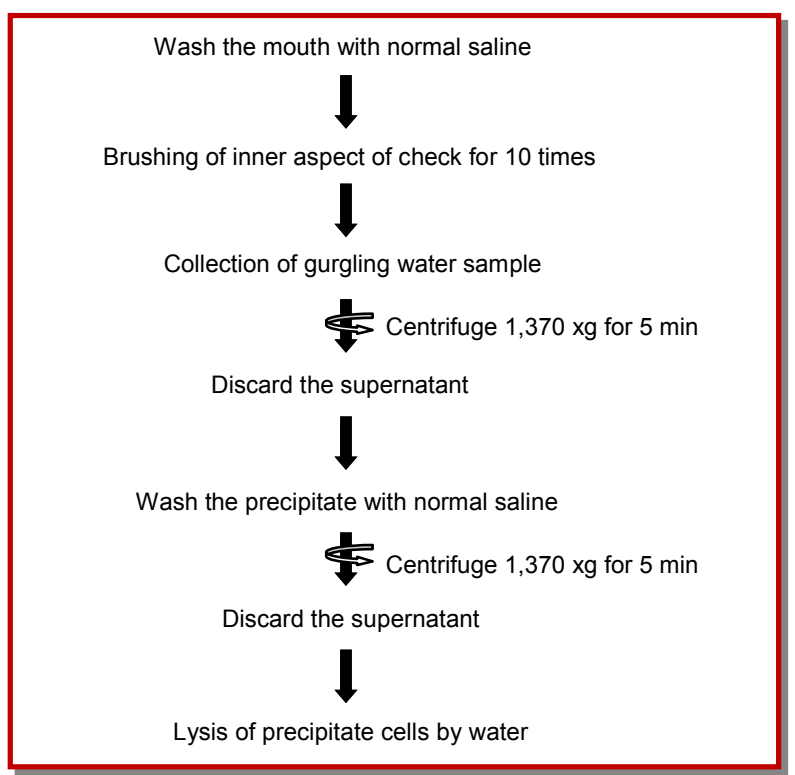

Figure 2: Steps of collection of buccal cells

Sheikh Mujib Medical University. All subjects enrolled in this study were explained about the nature and purpose of the study in easily understandable local language (Bangla). An informed written consent was taken from each subject.

\section{Data collection procedures}

After taking the informed written consent, detailed history was taken by interviewing. Clinical examinations were done focusing on melanosis and palmar keratosis of the participants and recorded in data collection form. The result of the study was recorded in separate sheet.

\section{Collection of samples}

Water, nail, blood and buccal mucosal cells were collected from all participants. Water sample and nail were collected once just before selection of each participant to confirm the diagnosis. At first one drop of $10 \%$ nitric acid was added to each plastic container. And then 50 $\mathrm{mL}$ of tube well water was collected in that container from each participant with ID number. With all aseptic precaution $5 \mathrm{~mL}$ venous blood was drawn and processed for centrifuge locally. Then serum was separated and was labeled for estimation of vitamin $\mathrm{E}$ and cholesterol. For the collection of buccal mucosal cells, the procedure was used as mentioned in Figure 2.

All the samples (blood and buccal cells) were then transported to the laboratory on the same day of collection and stored at $-20^{\circ} \mathrm{C}$ until analysis.

\section{Distribution of drugs}

Each patient received an envelope containing 15 caplets (drugs for 2 weeks). Each caplet contains vitamin E (200 IU). Each patient was advised to swallow one caplet daily, with sufficient amount of drinking water for 20 weeks without any interval. Immediately after taking vitamin E, placing tick marks in the appropriate space printed on the envelope. Each patient was also advised to keep his/her used blisters, and brought them during the next visit in order to ensure adherence.

\section{Estimation of samples}

The amount of total arsenic was estimated by SDDC method (AOAC, 1975). Vitamin E was estimated by a modified method (Baker and Frank, 1968). The cholesterol levels in buccal cells and serum were estimated by enzymatic (CHOD-PAP) method using Kit. The amount of protein was estimated by spectrophotometric method (Lowry et al., 1951)

\section{Statistical analysis}

Statistical analysis was performed using PASW (formerly known as SPSS) software version 18 for windows. Paired " $t$ " test was done for comparisons among same group. Unpaired " $t$ " test was done for comparison among different groups. $\mathrm{P}$ value $<0.05$ was considered as significant. The data were expressed as mean \pm SD.

\section{Result}

The mean $( \pm$ SD) age of patients was $40.4 \pm 14.7$ years, whereas it was $38.6 \pm 12.8$ years in arsenic exposed controls, and was $35.6 \pm 10.4$ years in healthy volunteers (Table I).

All patients $(n=19)$ showed the classical rain drop or diffuse cutaneous manifestation of melanosis, leucomelanosis and palmer keratosis. The mean duration of arsenic exposure of patients and arsenic exposed controls were similar: $16.8 \pm 2.9$ vs $15.4 \pm 4.5$ years.

The mean amount of arsenic in the tube well water of patients, arsenic exposed controls and healthy volunteers were $199 \pm 4.7,199 \pm 4.7,10.5 \pm 2.1 \mu \mathrm{g} / \mathrm{L}$ respectively. Patients and arsenic exposed controls shared same water source. The mean duration of onset of symptoms in patients was $8.9 \pm 1.9$ years.

The vitamin E level in buccal cells of healthy volunteers was $17.2 \pm 4.4 \mu \mathrm{g} / \mathrm{mg}$ of protein (Table II). But it was slightly decreased in arsenic exposed controls (16.0 \pm 6.4 $\mu \mathrm{g} / \mathrm{mg}$ of protein). There was significant decrease in patients $(12.3 \pm 6.1 \mu \mathrm{g} / \mathrm{mg}$ of protein). This change of patients was statistically more significant $(p=0.012)$ when compared with healthy volunteers. After vitamin E supplementation for 20 weeks, vitamin E level in buccal cell of healthy volunteers were not changed significantly but there were significant increase in arsenic exposed controls $(p=0.017)$ and in patients $(p=$ $0.044)$. 
Table I

Selected characteristics of the participants

\begin{tabular}{|lccc|}
\hline Characteristics & Patients & Arsenic exposed controls & Healthy volunteers \\
\hline Number (n) & 19 & 14 & 13 \\
Age (Years) & $40.4 \pm 14.7$ & $38.6 \pm 12.8$ & $35.6 \pm 10.4$ \\
Duration of arsenic exposure (years) & $16.8 \pm 2.9$ & $15.4 \pm 4.5$ & - \\
Duration of symptoms (years) & $8.9 \pm 1.9$ & - & - \\
Amount of arsenic in water (mg/L) & $199 \pm 4.7$ a & $199 \pm 4.7$ a & $10.5 \pm 2.1$ \\
Data are presented as mean $( \pm$ SD); apatients and exposed controls had same source of drinking water & \\
\hline
\end{tabular}

Table II

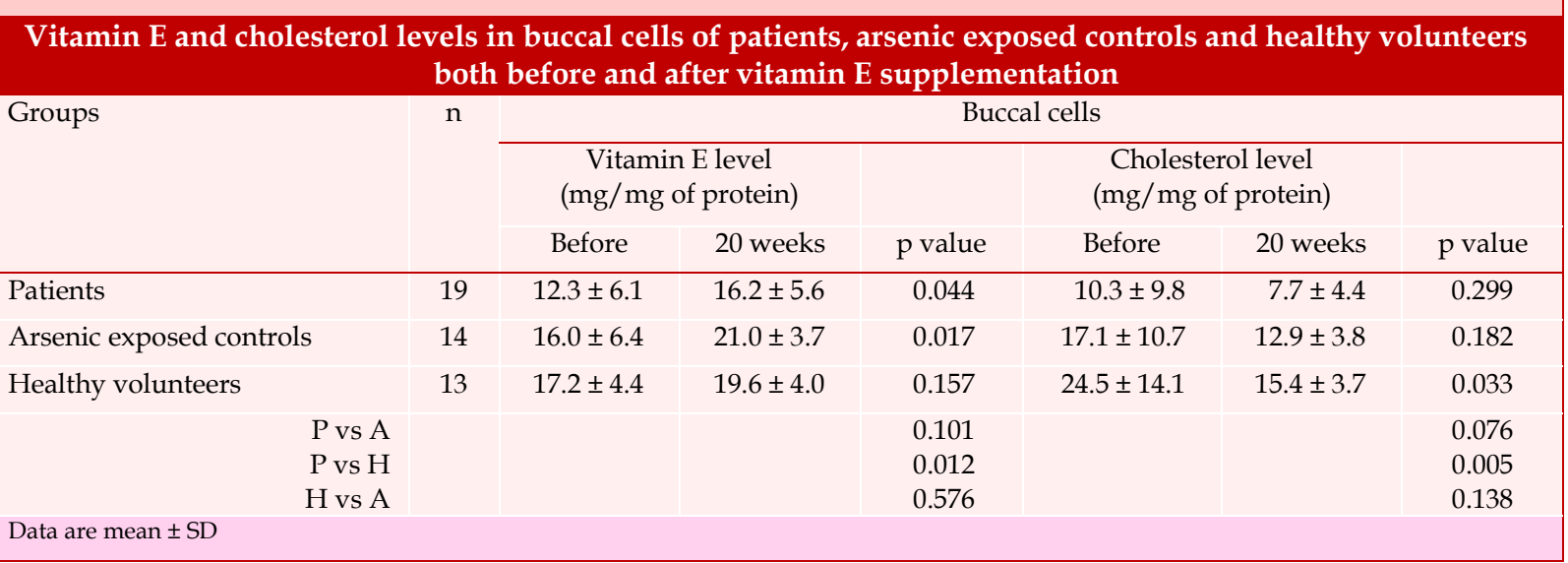

The mean vitamin $\mathrm{E}$ level in the serum of healthy volunteers was $18.9 \pm 4.4 \mu \mathrm{g} / \mathrm{mL}$ which was decreased to $15.3 \pm 2.9 \mu \mathrm{g} / \mathrm{mL}$ in arsenic exposed controls (Table III). But in case of patients, it was almost half the amount present in the healthy volunteers $(10.2 \pm 2.6$ $\mu \mathrm{g} / \mathrm{mL})$. That means, patients showed reduce serum vitamin $\mathrm{E}$ level. The comparison between healthy volunteers vs. arsenic exposed controls $(p=0.019)$ and healthy volunteer vs. patients $(p=0.000)$. Both of the results were highly statistically significant. Supplementation with vitamin $\mathrm{E}$ for 20 weeks showed increase in the serum vitamin E levels in all the groups. All of these results were statistically highly significant. The decreased level of vitamin $E$ in buccal cells also reflected the decreased serum concentration of vitamin $\mathrm{E}$ in patients.

The cholesterol level in buccal cells of healthy volunteers was $24.5 \pm 14.1 \mu \mathrm{g} / \mathrm{mg}$ of protein, which decreased to $17.1 \pm 10.7 \mu \mathrm{g} / \mathrm{mg}$ of protein in arsenic exposed controls. But in case of patients, it was significantly lower $(10.3 \pm 9.8 \mu \mathrm{g} / \mathrm{mg}$ of protein) than the healthy volunteers. That means, patients showed marked decreased level of cholesterol in buccal cells. When the result was compared with different groups, only healthy volunteers vs. patients showed statistically highly significant result $(\mathrm{p}=0.005)$. After 20 weeks supplementation of vitamin $\mathrm{E}$, there were no significant change occurred in arsenic exposed controls and patients but significant change occurred in healthy volunteers $(\mathrm{p}=0.033)$.

The serum cholesterol level in healthy volunteers was $153.5 \pm 22.8 \mathrm{mg} / \mathrm{dL}$ and it decreased slightly in arsenic exposed controls $(147.0 \pm 34.5 \mathrm{mg} / \mathrm{dL})$. But the level markedly decreased in patients $(125.3 \pm 37.0 \mathrm{mg} / \mathrm{dL} ; \mathrm{p}=$ 0.012). After treatment with vitamin E for 20 weeks, there were no significant changed observe in all three study groups.

\section{Discussion}

The present study shows that arsenic exposure decreases the level of vitamin $\mathrm{E}$ in serum without significant change in buccal cells. In patients, both serum and buccal cells show significant decrease in vitamin $\mathrm{E}$ level. Chronic arsenic exposure does not alter the cholesterol levels in both serum and buccal cells but it is decreased in patients. Supplementation with vitamin E increases the vitamin $\mathrm{E}$ level both in serum and buccal cells of arsenic exposed controls and patients without any significant change in cholesterol level.

Chronic ingestion of arsenic exerts its harmful effects by boosting the body's production of free radicals. Incre- 
Table III

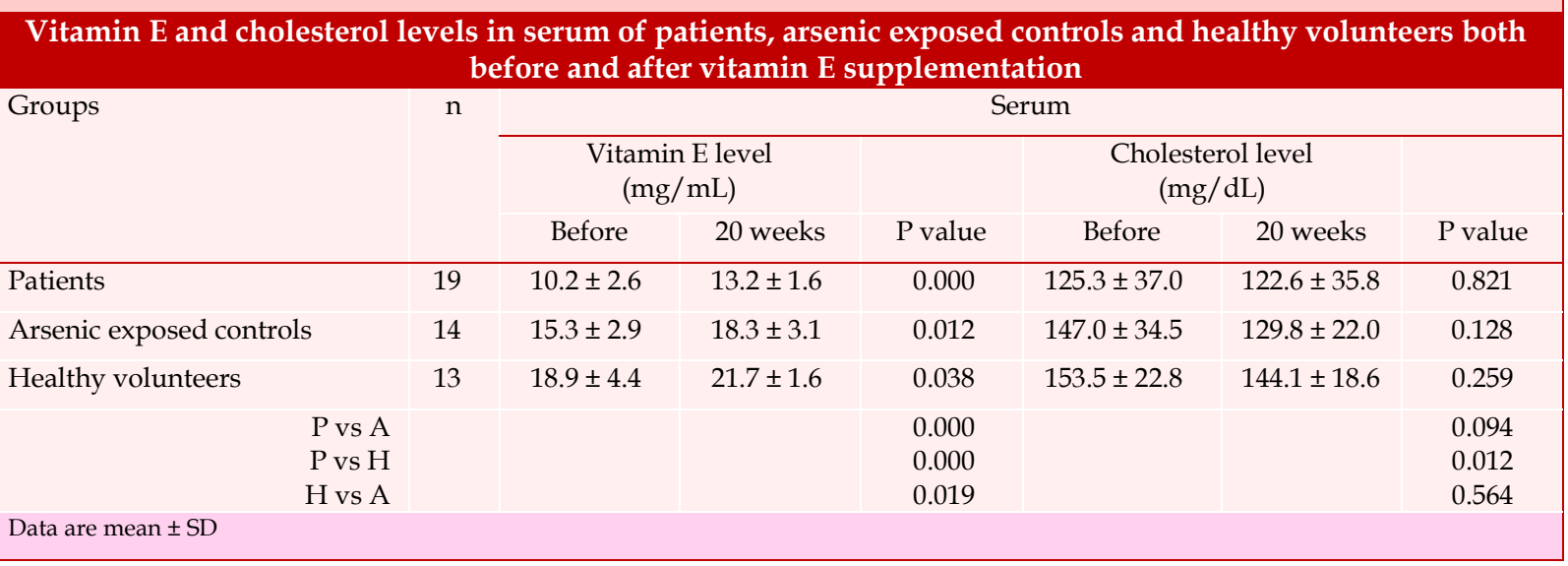

ased free radical decreases the level of anti-oxidant capacity in plasma (Wu et al., 2001). Reduced glutathione levels in red blood cells of arsenicosis patients are reduced (Sinha et al., 2003). Vitamin E is a lipidsoluble anti-oxidant vitamin present in biological membranes. It contains a hydroxyl group by which it reacts with unpaired electrons and can reduce, e.g., peroxyl radicals. Vitamin $\mathrm{E}$ is absorbed in the intestine and transported to the liver in chylomicrons. It is returned to the blood in VLDL particles that with lipoprotein lipase are degraded to LDL. LDL particles provide cells in peripheral tissues with cholesterol. Only 5-10 molecules of vitamin E exist in each LDL. Vitamin E may lower LDL cholesterol in our body by inhibiting LDL oxidation. LDL oxidation is a process that damages cells in our body. Oxidative stress causes a rapid depletion of vitamin $C$ and vitamin $E$ (Bouayed and Bohn, 2010). Vice versa, deficiency of vitamin $\mathrm{E}$ has also shown to provoke oxidative stress disturbances in transgenic rats. Vitamin E is also reduced. However, buccal cells still maintained its normal value. In case of patient, buccal cells fails to maintain vitamin E level as the blood vitamin E level is severely reduced. Plasma vitamin E levels are significantly inversely related to urinary total arsenic concentrations and inorganic arsenic percentage, and significantly positively related to dimethylarsinic acid percentage (Chung et al., 2011). Low levels of vitamin $\mathrm{E}$ in both serum and buccal cells may be explained by increased demand of vitamin $\mathrm{E}$ instead of inadequate absorption from gut. Increased demand of vitamin $\mathrm{E}$ is due to its important role in scavenging free radical. Vitamin E prevents arsenicinduced protein oxidation and DNA damage in rats (Kadirvel et al., 2007). In addition, vitamin E may be cosecreted with arsenic from the buccal cells, like the skin of arsenicosis patients (Yousuf et al., 2011). Supplementation with vitamin $\mathrm{E}$ increases the vitamin $\mathrm{E}$ level both in serum and buccal cells of arsenic exposed controls and patients.
Chronic exposure to arsenic in drinking water and food does not influence the levels of total cholesterol in serum. But in patients of arsenicosis it is decreased in comparison to healthy Bangladeshi individuals but it is within normal range. Low serum cholesterol level in patient is also reported elsewhere (Nabi et al., 2005). After 20 weeks supplementation of vitamin E, we found no significant changed observe in all three study groups.

\section{References}

Ahmad SA, Faruquee MH, Sayed MHSU, Khan MH, Hadi SA, Khan AW. Chronic arsenic poisoning management by vitamin A, E, C regimen. J Pre Social Med (JOPSOM). 1998; 17: 19-26.

AOAC (Association of Official Analytical Chemists 25. 006) $12^{\text {th }}$ ed. $1975, \mathrm{p} 428$.

Baker H, Frank O. Determination in serum tocopherol. In: Practical clinical biochemistry. Gowenlock AH.(ed). 6th ed. London, Heinemann Medica books, 1968, p 902.

Bouayed J, Bohn T. Exogenous anti-oxidants: Double-edged swords in cellular redox state. Oxid Med Cell Longev. 2010: 4: 228-37.

Caussy D. A field guide for detection, management and surveillance of arsenicosis cases. New Delhi, WHO Regional Office for South-East Asia, 2005.

Choudhry ZK, Misbahuddin M, Hosain AKMM, Saleh AA. Inhibitory effect of arsenic on aerobic gut flora in rat. Bangladesh Med Res Counc Bull. 2009; 35: 79-83.

Chowdhury NJA, Mir Misbahuddin M, Rahman MS. Corn extracts lower tissue arsenic level in rat. Bangladesh Med Res Counc Bull. 2009; 35: 21-25.

Chung CJ, Pu YS, Chen YT, Su CT, Wu CC, Shiue HS, Huang CY, Hsueh YM. Protective effects of plasma alpha-tocopherols on the risk of inorganic arsenic-related urothelial carcinoma. Sci Total Environ. 2011; 409: 1039-45. 
de Wiele TV, Gallawa CM, Kubachk KM, Creed JT, Basta N, Dayton EA, Whitacre S, Laing GD, Bradham K. Arsenic metabolism by human gut microbiota upon in vitro digestion of contaminated soils. Environ Health Perspect. 2010; 118: 1004-09.

Fariduddin AKM, Misbahuddin M, Manun MIR, Nahar N. Alcohol extract and residue of spirulina in the prevention of accumulation of arsenic in rats. Bangladesh J Physiol Pharmacol. 2001; 17: 15-17.

Hall AF. Arsenical keratosis disappearing with vitamin A therapy. Arch Derm Syph. 1946; 53: 154.

Kadirvel R, Sundaram, Mami S, Samuel S, Elango N, Parnneerselvam C. Supplementation of ascorbic acid and alpha-tocopherol prevents arsenic-induced protein oxidation and DNA damage induced by arsenic in rats. Human Exp Toxicol. 2007; 26: 939-46.

Kamaluddin M, Misbahuddin M. Zinc supplement reduces tissue arsenic concentration in rats. Bang Med Res Counc Bull. 2006; 32: 87-91.

Khan MAR, Misbahuddin MS, Khandker S, Ifthaker-AlMahmud. Arsenic estimation in foodstuffs of arsenic exposed areas in Bangladesh. In: Applied research on arsenic in Bangladesh. Misbahuddin M (ed). World Health Organization, Dhaka, 2007, pp 31-42.

Lowry $\mathrm{OH}$, Rosebrough NJ, Farr AL, Randall RJ. Protein measurement with the Folin phenol reagent. J Biol Chem. 1951; 193: 265-75.

Misbahuddin M, Bashar T, Hossain MA. Effectiveness of garlic oil in the treatment of arsenical palmer keratosis. Bangladesh J Pharmacol. 2013: 8: 22-27.

Misbahuddin M, Islam AZ, Khandker S, Ifthaker-Al-Mahmud, Islam N, Anjumanara. Efficacy of spirulina extract plus zinc in patients of chronic arsenicosis poisoning: A randomized placebo-controlled study. Clin Toxicol (Phila). 2006; 44: 13541.

Misbahuddin M, Kamaluddin M. Simultaneous administration of zinc and arsenic enhances accumulation in tissues. BMJ (rapid response) 14 November, 2002.

Misbahuddin M, Khandker S, Jakariya M. Arsenic contamination of drinking water and foodstuffs. In: Drin- king water contaminants in Bangladesh: Focuses on arsenic, fluoride, pesticides, manganese and cyanobacteria. Misbahuddin M, Khandker S (eds). Lambert Academic Publishing, Germany, 2011, pp 12-57.

Nabi AHMN, Rahman MM, Islam LN. Evaluation of biochemical changes in chronic arsenic poisoning among Bangladeshi patients. Int J Environ Res Public Health. 2005; 2: 385-93.

Nasir M, Misbahuddin M, Ali SMK. Selenium intervention in reducing arsenic levels in different tissues. In: Bangladesh Environment 2002, Proceedings of the 2nd International Conference on Bangladesh Environment. Ahmed MF, Tanveer SA, Badruzzaman ABM (eds). ICBEN-2002, Dhaka, Bangladesh, 2002, pp 343-52.

Rahman MF, Misbahuddin M. Effect of folic acid and tetrahydrofolate on tissue arsenic level in rat. Bangladesh J Pharmacol. 2010; 5: 25-29.

Saha B. Effect of ascorbic acid on reduced glutathione level in arsenic-loaded isolated liver tissues of rat. Bangladesh J Pharmacol. 2006; 1: 68-71.

Sinha SK, Misbahuddin M, Ahmed ANN. Factors involved in the development of chronic arsenic poisoning in Bangladesh. Arch Environ Health. 2003; 58: 699-700.

Tabassum NE. Effect of alpha-lipoic acid on the removal of arsenic from arsenic-loaded isolated liver tissues of rat. Bangladesh J Pharmacol. 2006; 1: 27-32.

Umar BU. Effect of hexane extract of spinach in the removal of arsenic from rat. Bangladesh J Pharmacol. 2007; 2: 27-34.

Wu M, Chiou HY, Wang TW, Hsuch YM, Wang IH, Chen CJ, Lee TC. Association of blood arsenic levels with increased reactive oxidants and decreased antioxidant capacity in a human population of northeastern Taiwan. Environ Health Perspect. 2001; 109: 1011-17.

Yafang S, Gan Z, Jinsong B. Total phenolic content and antioxidant capacity of rice grains with extremely small size. Afr J Agric Res. 2011; 6: 2289-93.

Yousuf AKM, Misbahuddin M, Rahman MS. Secretion of arsenic, cholesterol, vitamin E, and zinc from the site of arsenical melanosis and leucomelanosis in skin. 2011; 49: 374 -78 . 